\title{
The Perspective of Demographic Variables on Dynamic Capabilities in the Context Indonesian Traditional Market Trader
}

\author{
Moh Farid Najib \\ Business Administration Department, \\ Bandung State Polytechnic, Indonesia
}

Doi: $10.2478 / \mathrm{mjss}-2018-0051$

\begin{abstract}
This study motivated by the need to understand the determinants of dynamic capabilities in the traditional market traders in the context of the Indonesian traditional market. The purpose of this paper is to examine the relationship of demographic variables such as gender, level of education and experience with the dynamic capabilities of traditional market traders. A survey has a to 400 traders of traditional markets in 16 traditional markets around Bandung, Indonesia. One-way ANOVA is used to test different groups, and previously the reliability and homogeneity of variance. The result of this research that there is no difference of demography (gender, level of education and experience) on the dynamic capabilities of traditional market traders in Bandung. The same is true for each dimension, they are; sensitivity capability, absorption capability, integration capability and innovation capability. Nevertheless, there are several dimensions with different capabilities seen from a gender for absorptive the and innovation capabilities, and experience for sensitivity capabilities.
\end{abstract}

Keywords: demographic and dynamic capabilities

\section{Introduction}

The Indonesian Retail Report (2013) is associated with the growth in the value of sales share in supermarkets/hypermarkets and minimarkets when compared to traditional markets. Shows that the market share of traditional market share tends to decline since 2002 , amounted to $74.8 \%$, then in 2005 fell to $67.6 \%$ and in 2011 fell to $55.8 \%$. Suryadarma, Poesora; Budiyati, Akhmadi, and Rosfadhila (2007) from his research mentioned there are 11 (eleven) causes of business sluggishness in traditional market, that is; lack of buyers, increased competition with other traders, increased competition with supermarkets, higher prices, increased competition with street vendors, higher supplier prices, increasing competition with minimarket, worsening market conditions, increasingly difficult supply of goods, and access to credit is increasingly difficult.

However, in order to reduce traditional market failures by enhancing its dynamic capabilities, as Hou (2008) argues that the concept of dynamic capabilities has enhanced a resource-based view by overcoming the evolutionary nature of corporate resources and capabilities in relation to environmental change and permitting the identification of specific processes company or industry that it is important for the evolution of a company or industry. Furthermore, Tsai and Shih (2013) state that a strategy of downsizing responsibility can improve the performance of larger enterprises for the development and improvement of the company's dynamic capabilities. Wang and Shi (2011) dynamic capabilities is very important for every organization, especially micro, small and medium enterprises (SMEs) to compete and succeed in the business environment, due to lack of MSME resources and vulnerability to lead and fierce competition.

Research on dynamic capabilities has created a focus of research on processes within a 
company aimed at developing and renewing its resource base to cope with dynamic environmental change (Teece, 2007; Hou, 2008; Pavlou and El Sawy, 2011; Zheng, Zhang, Wu and Du, 2011). However, demographic variables such as gender, educational level, and work experience determine the degree of dynamic capabilities of business actors, as Hambrick and Mason (1984) argue that demographic characteristics influence the decisions they make and therefore the actions adopted by the organizations to which they lead. Brush (1992) found that individual dimensions such as age, education, and work experience affect business performance.

The purpose of this study is to evaluate the relationship of retail service quality on satisfaction and trust and impact on loyalty in the context of the Indonesian traditional market. So, the objectives of this research are to determine the effect of the perspective demographic variable (such as gender, level of education and experience) on dynamic capabilities of the traditional market trader.

\section{Literature Review and Hypothesis}

\subsection{Dynamic Capabilities}

Teece (2007) defined that dynamic capabilities are a capability that emphasizes the transformation of environmental characteristics and how the firms manage to adapt, and integrate, and reconfigure internal and external organizational resources to compete with dynamic environmental conditions. Hou (2008) defined dynamic capabilities as the company's capability to deploy new configurations of the operational competencies relative to competition with effective environmental sensitivity, as well as absorption, integration and innovative engagement.

Meanwhile, Pavlou and El Sawy (2011) defined that the dynamic capabilities as capabilities that assist in internal parts extend, modify, and reconfigure existing operational capabilities to new capabilities more suited to environmental change. Dynamic capabilities are defined by Zheng, et al, (2011) as the company's capability to integrate, build, and reconfigure internal and external competencies to cope with rapidly changing environments. Lin and Huang (2012) argue that dynamic capabilities can be found positively related to innovation in products since product innovation is a very important aspect in a competitive global market where economics and technology continue to change at an uncertain rate. Dadashinasab and Sofian (2014) the dynamic capabilities as the company's capability to update, integrate, recreate and reconfigure their capabilities and resources, and the effect of dynamic capabilities.

Therefore, some experts provide groups or the dimensions of dynamic capabilities. Teece (2007) distinguishes the dynamic capabilities into 3 (three), namely; (1) the capability to perceive opportunities and threats, (2) the capabilities to seize opportunities, and (3) the capabilities to maintain competitiveness through enhancement, integration, protection, and, if necessary, reconfiguration of tangible and intangible corporate assets. Hou (2008) mentions that the core component of dynamic capabilities consists of; sensitivity capability, absorptive capability, integration capability, and innovation capability (Hou, 2008, Najib, Kartini, Suryaatmaja and Sari, 2017). Pavlou and Elsawy (2011) mentioned that dynamic capabilities consist of; sensitivity capabilities, learning capabilities, integration capabilities, and coordination capabilities. While Zheng et al (2011) mentioned the dynamic capabilities include; knowledge acquisition capabilities, knowledge generation capabilities, and, knowledge combination capabilities. Wang and Shi (2011) mentioned that dynamic capabilities consist of; market response capability, learning capability, coordination capability and integrative capability. Gathungu and Mwangi (2012) divide the dynamic capabilities into; sensing capability, learning capability, integrative capability and coordination capability. Next, Nedzinskas et al (2013) mention the dynamic capabilities include; sensing capability, seizing capability, reconfiguring capability, and Tiantian et al (2014) divided the dynamic capabilities into integrative capability, absorptive capability, and innovation capability.

\subsection{Demographic Variables and Dynamic Capabilities}

Hambrick and Mason (1984) mentioned that demographic characteristics (such as gender, 
educational level, and experience) influence in the decisions they make, and therefore the actions adopted by the organizations they lead. Furthermore, Brush (1992) found that individual dimensions such as age, education, and work experience affect business performance. On the other hand, the level of education affects performance. Some studies support this view (Box, White, and Barr, 1993) suggests that better-educated managers are more receptive to new ideas. In addition, since formal education can help one accumulate absorptive capacity, such as self-confidence, knowledge, and skills (Daneels, 2008), highly educated of entrepreneurs can produce a successful performance. An entrepreneur's experience is positively correlated with performance (Box et al., 1993; Box, Watts, and Hisrich, 1994; Cooper, 1981; Yusuf, 1995). Boohene (2009) finds that a lack of education and work experience contribute to the inability of female owners to effectively manage a business. Therefore, the hypothesis is;

$\mathrm{H}_{1}$ : Differences in gender will affect on the dynamic capabilities of traditional market traders with their sub-hypotheses; $\mathrm{H}_{1.1}$ Gender differences will affect the sensing capability; $\mathrm{H}_{1.2}$ Gender differences affect the absorptive capability; $\mathrm{H}_{1.3}$ Gender differences will affect the integration capability; $\mathrm{H}_{1.4}$ Gender differences will affect the innovation capabilities.

$\mathrm{H}_{2}$ : The different levels of education will affect the dynamic capabilities of traditional market traders with their sub-hypotheses; $\mathrm{H}_{2.1}$ The different levels of education will affect the sensing capability; $\mathrm{H}_{2.2}$ The different levels of education will affect the absorptive capability; $\mathrm{H}_{.2 .3}$ The different levels of education will affect the integration capabilities; $\mathrm{H}_{2.4}$ The different levels of education will affect the innovation capabilities.

$\mathrm{H}_{3}$ : Differences in experience of the trader will affect the dynamic capabilities of traditional market traders with their sub-hypotheses; $\mathrm{H}_{5.1}$ The difference in experience will affect the sensing capability; $\mathrm{H}_{5.2}$ The difference in experience will affect the absorptive capability; $\mathrm{H}_{5.3}$ The difference in experience will affect the integration; $\mathrm{H}_{5.4}$ The difference in experience will affect the innovation capability.

\section{Methodology}

\subsection{Questionnaire design}

The questionnaire was developed to adopt the concept of capabilities by Hou (2008) and Najib et al (2017) where the dynamic capabilities consist of sensing capability, absorption capability, integration capability and innovation capability. Questionnaires used to collect data will use a Likert scale. Likert scale most often used is summated rating scales. Its scales consist of statements that express an attitude, either favorable or unfavorable to an interesting object (Cooper and Schindler, 2014).

Each item is ranked according to the Likert Scale Summated Rating method with five alternative answers; 1-2-3-4-5. Respondents' choice of answers is the answer score for each item. This means that the Likert Scale can compare a respondent's score with the well-defined distribution of scores from the sample group. Sekaran and Bougie (2009) mentioned that Likert scale is designed to test how strongly respondents agree or disagree with the given statement.

\subsection{Sample}

This research used a non-probability sampling item, namely convenience sampling. A sample size of 400 traders of the traditional market was collected. The sample size Considered representative since the respondents collected randomly from 12 traditional markets around Bandung, Indonesia.

\subsection{Analysis}

Data were tested by reliability testing. Then further analysis through descriptive analysis and One Way ANOVA test to test the difference of the average of independent data groups. Data were tested by reliability testing. Then further analysis through descriptive analysis and One Way ANOVA test to evaluate the difference of the average of independent data groups. Operational 
calculations apply for SPSS program.

\section{Results}

\subsection{Respondent's profile}

This study was conducted in 12 traditional markets in Bandung City, with a sample size of 400 respondents of traditional market traders. Profile of respondents from traders of the traditional market as shown in table 1.

Tabel 1: Profil Respondent

\begin{tabular}{|l|c|c|l|c|c|}
\hline Descriptions & Freq & $\mathbf{\%}$ & Description & Freq & $\%$ \\
\hline A. Level of Education & & & B. Experience & & \\
\hline 1. Elementary School & 44 & $11 \%$ & 1. Over 15 years & 50 & $13 \%$ \\
\hline 2. Junior High School, & 112 & $28 \%$ & 2. 10 years to 15 years & 57 & $14 \%$ \\
\hline 3. Senior High School & 223 & $56 \%$ & 3. 5 years to 10 years & 9 & $2 \%$ \\
\hline 4. Diploma-III & 13 & $3 \%$ & 4. Less than 5 years & 43 & $11 \%$ \\
\hline 5. Bachelor/Diploma IV & 8 & $2 \%$ & Total & 19 & $5 \%$ \\
\hline Total & $\mathbf{4 0 0}$ & $\mathbf{1 0 0} \%$ & C. Gender & & \\
\hline & & & a. Man & 218 & $55 \%$ \\
\hline & & & b. Female & $\mathbf{4 0 0}$ & $\mathbf{1 0 0} \%$ \\
\hline
\end{tabular}

\subsection{Reliability Analysis}

Reliability analysis is a test of the level of stability, accuracy, consistency, and level of homogeneity of measuring instruments used in a study. A good question is a clear question, easily understood by the respondent, detailed, high consistency, unambiguous, non-causal; Obviously and the language used is to be the language of the respondents in question. Good questionnaires are used over and over again but will get consistent and consistent answers from the respondents. Reliability test is measured by using a Cronbach Alpha coefficient. (Malhotra, Baalbaki and Bechwati 2003; Nunally, 1978), reliability is satisfactory if the Cronbach Alpha coefficient is more than 0.7 , so reliability is said to be very reliable. The reliability results of dynamic capabilities of traditional market traders in Bandung City as shown in table 2.

Table 2: Reliability Statistics of Dynamic Capabilities

\begin{tabular}{lcc}
\hline Variable/Dimensions & Number of items & Reliability Statistics (Cronbach's' Alpha) \\
\hline Overall Scale & 16 & 0,851 \\
\hline Sensing Capability & 4 & 0,714 \\
\hline Absorptive Capability & 4 & 0,780 \\
\hline Integration Capability & 4 & 0,794 \\
\hline Innovation Capability & 4 & 0,881 \\
\hline
\end{tabular}

Based on table 2 shows that the Cronbachs' Alpha for each dimension as well as the outcome, it shows reliable or unreliable results, whereas the overall Cronbachs' Alpha value is 0.851 . Similarly, for each dimension, where the Cronbachs' Alpha values are all above 0.7, as Malhotra, Baalbaki, and Bechwati (2003), and Nunally (1978), say that Cronbach Alpha values above 0.7 are very reliable.

\subsection{Test of Homogeneity of Variance}

The test of Homogeneity of Variance describes the homogeneity test. The assumption in ANOVA testing is that the data group variant is the same or homogeneous. The test criterion is if the 
significance $<0.05$, then the data group variance is not the same, if the significance $>0.05$, then the data group variant is the same. The homogeneity test of demographic factors consisting of, sex, level of education, and duration of effort from traditional market traders in Bandung, to its dynamic capabilities along with its dimensions consisting of; sensing capability, absorptive capability, integration capability and innovation capability, as shown in table 3.

Table 3: Test of Homogeneity of Variances

\begin{tabular}{|l|l|c|c|c|c|}
\hline Demographic Factors & $\begin{array}{l}\text { Dimension and } \\
\text { Sub Dimension }\end{array}$ & Levine Statistic & df1 & df2 & Sig. \\
\hline \multirow{5}{*}{ Gender } & Sensing Capability &, 001 & 1 & 398 &, 977 \\
& Absorptive Capability & 9,848 & 1 & 398 &, 002 \\
& Integration Capability &, 411 & 1 & 398 &, 522 \\
& Innovation Capability & 4,252 & 1 & 398 &, 040 \\
& Dynamic capabilities &, 954 & 1 & 398 &, 329 \\
\hline \multirow{5}{*}{ Level of Education } & Sensing Capability & 1,251 & 4 & 395 &, 289 \\
& Absorptive Capability & 1,107 & 4 & 395 &, 353 \\
& Integration Capability & 1,476 & 4 & 395 &, 209 \\
& Innovation Capability &, 663 & 4 & 395 &, 618 \\
& Dynamic capabilities & 1,764 & 4 & 395 &, 135 \\
\hline \multirow{5}{*}{ Experience } & Sensing Capability & 7,578 & 1 & 398 &, 006 \\
& Absorptive Capability &, 913 & 1 & 398 &, 340 \\
& Integration Capability &, 704 & 1 & 398 &, 402 \\
& Innovation Capability & 2,056 & 1 & 398 &, 152 \\
& Dynamic capabilities &, 327 & 1 & 398 &, 568 \\
\hline
\end{tabular}

The finding showed in Table 4.8 describes the homogeneity test, the assumption in ANOVA testing is that the data group variances are the same and homogeneous. Testing criteria is if the significance $<0.05$, then the data group variants are not equal, and if the significance $>0.05$, then the data group variant is the same.

From the SPSS output as table 4.8 for gender to dynamic capabilities can be seen significance $>0,05(0,329>0,05)$. So it can be concluded that the variants of both groups of men and women are equal, so this has fulfilled the basic assumptions. When considered on subdimensions, namely; sensing capability can be seen significance> $0,05(0,977>0,05)$ and integration capability can be seen significance> $0,05(0,522>0,05)$, so it can be concluded for sensing capability and integration capability that the variants of both groups of men and women are the same, then this has fulfilled the basic assumption. However, for absorption capability and innovation capability the level of significance are $<0.05,(0.02<0.05)$ for absorptive capability and $(0.040<0.05)$ for innovation capability, so it can be concluded that the second variant groups of men and women are not the same, then this does not meet the basic assumptions.

From the test output of the Homogeneity of Variance for the level of education of dynamic capabilities can be seen significance> $0,05(0,235>0,05)$. So it can be concluded that the variants of the five groups of level education, that are an elementary school, junior high school, senior high school, diploma III and bachelor/Diploma IV are the same, then this has fulfilled the basic assumption. Likewise for sub-dimensions, namely; for sub dimension of sensing capability can be seen significance $>0,05(0,289>0,05)$, sub dimension of absorptive capability with significance value $>0,05(0,353>0,05)$, sub dimension of integration capability with significance value $>0,05$ $(0,209>0,05)$, and sub dimension of innovation capability with significance value $>0,05(0,618>$ $0,05)$, so can be concluded that all of dimension that are; sensing capability, absorptive capability, integration capability and innovation capability that variants of the five group of level education, that are; elementary, junior high, high school, DII and S1 / DIV levels are the same, so this has fulfilled the basic assumption

As Table 4.8 presented for the experience variable with dynamic capabilities can be seen significance $>0,05(0,568>0,05)$. So it can be concluded that the variant of the experience that has been more than 15 years, between 10 to 15 years, between 5 to 10 years and less than 5 years are 
the same, then this has fulfilled the basic assumption. When considered on each dimensions, namely; absorption capability with significance value $>0,05(0,340>0,05)$, integration capability with significance value $>0,05(0,402>0,05)$, and innovation capability with significance value $>0,05$ $(0,152>0,05)$, so it can be concluded for absorption capability, integration capability and innovation capability that variant of four groups that the trader have experience more than 15 years, between 10 to 15 years, between 5 to 10 years and less of 5 years are the same. This has fulfilled the basic assumption. In contrast, for sub-dimensions of the sensing capability the level of significance is $<0.05,(0.006<0.05)$, so it can be concluded that the variance of the trader have experience for more than 15 years, between 10 to 15 years, between 5 to 10 years and less than 5 years is not the same, then this does not meet the basic assumptions.

\subsection{One-Way ANOVA}

One Way ANOVA is used to test the differences of the demographic group consisting of; gender, level of education, and experience of traditional market traders in Bandung related to the dynamic capabilities with the dimensions. That is; sensing capability, absorptive capability, integration capability and innovation capability.

\subsubsection{Gender}

The respondent's perception of the dimensions of dynamic capabilities in terms of the gender by using One Way -ANOVA Test. The purpose of this test is to determine whether there are differences in dynamic capabilities and dimensions of the traders of traditional markets in Bandung between male and female traders. For more details can be folded in table 4 .

Table 4: ANOVA - Gender

\begin{tabular}{|ll|c|c|c|c|c|}
\hline & & Sum of Squares & df & Mean Square & F & Sig. \\
\hline \multirow{3}{*}{ Sensing Capability } & Between Groups & 5659.598 & 1 & 5659.598 & 2.238 & .135 \\
& Within Groups & 1006284.152 & 398 & 2528.352 & & \\
& Total & 1011943.750 & 399 & & & \\
\hline \multirow{3}{*}{ Absorptive Capability } & Between Groups & 16247.911 & 1 & 16247.911 & 4.233 & .040 \\
& Within Groups & 1527727.089 & 398 & 3838.510 & & \\
& Total & 1543975.000 & 399 & & & \\
\hline \multirow{3}{*}{ Integration Capability } & Between Groups & 15929.519 & 1 & 15929.519 & 3.172 & .076 \\
& Within Groups & 1998670.481 & 398 & 5021.785 & & \\
& Total & 2014600.000 & 399 & & & \\
\hline \multirow{3}{*}{ Innovation Capability } & Between Groups & 17679.585 & 1 & 17679.585 & 2.907 & .089 \\
& Within Groups & 2420514.165 & 398 & 6081.694 & & \\
\hline \multirow{2}{*}{ Dynamic capabilities } & Total & 2438193.750 & 399 & & & \\
& Between Groups & 13405.906 & 1 & 13405.906 & 6.190 & .013 \\
& Within Groups & 861950.934 & 398 & 2165.706 & & \\
\hline
\end{tabular}

The finding on table 4 it can be seen that the significance of the gender factor to dynamic capabilities and its dimensions if obtained $F_{\text {value }}>F_{\text {table }}\left(H_{0}\right.$ is rejected), which means there is the difference from gender factor to dynamic capabilities and its dimension. The output of SPSS on sensing capability obtained $F_{\text {value }}$ value is 2,238 with $F_{\text {table }}$ of 3,865 , then $F_{\text {value }}<F_{\text {table }}(2,238$ $<3,865)$, it is accepted by $\mathrm{H}_{0}$. So it can be concluded that there is no difference between male and female to the sensing capability of the traditional market traders in Bandung.

The SPSS output obtained a value of sensing capability ( $F$ value is 4.233 with a table of 3.865), it shows that value $>F_{\text {table }}\left(H_{\circ}\right.$ is rejected). Which means that there are differences in male and female on the absorptive capability of the traditional market traders in Bandung. The result also obtained a value of integration capability ( $F$ value is 3.172 with table equal to 3,865 ) it shows that 
$\mathrm{H}_{\mathrm{o}}$ is accepted. Which means that there is no difference between male and female to the integration capability of the traditional market traders in Bandung. The value of innovation capability ( $F_{\text {value }}$ is 2.907 with $\left.\mathrm{F}_{\text {table }}\right)$ it shows that $\mathrm{F}_{\text {value }}<\mathrm{F}_{\text {table }}\left(\mathrm{H}_{\mathrm{o}}\right.$ is accepted). Which means that there is no gender difference to the innovation capabilities of the traditional market traders in Bandung. The results of dynamic capabilities value ( $F_{\text {value }}$ is 6.190 with $F_{\text {table }}$ of 3.865$)$, it shows that $F_{\text {value }}>F_{\text {table }}\left(H_{\circ}\right.$ is rejected). Which means that there is no difference between male and female to dynamic capabilities of the traditional market traders in Bandung.

\subsubsection{Level of Education}

The results of dynamic capabilities in terms of an educational level using One Way -ANOVA Test is to determine whether there are differences in dynamic capabilities with the level of education of the traditional market trader (elementary school, junior high school, senior high school, D-III and D-IV / Bachelor). For more details can be folded in table 5 .

Table 5: ANOVA-Level of Education

\begin{tabular}{|ll|c|c|c|c|c|}
\hline & & Sum of Squares & df & Mean Square & $\mathrm{F}$ & Sig. \\
\hline \multirow{3}{*}{ Sensing Capability } & Between Groups & 16961.490 & 4 & 4240.372 & 1.683 & .153 \\
& Within Groups & 994982.260 & 395 & 2518.942 & & \\
& Total & 1011943.750 & 399 & & & \\
\hline \multirow{3}{*}{ Absorptive Capability } & Between Groups & 9678.592 & 4 & 2419.648 & .623 & .646 \\
& Within Groups & 1534296.408 & 395 & 3884.295 & & \\
& Total & 1543975.000 & 399 & & & \\
\hline \multirow{3}{*}{ Integration Capability } & Between Groups & 20455.221 & 4 & 5113.805 & 1.013 & .400 \\
& Within Groups & 1994144.779 & 395 & 5048.468 & & \\
\hline \multirow{3}{*}{ Innovation Capability } & Total & 2014600.000 & 399 & & & \\
& Between Groups & 62496.496 & 4 & 15624.124 & 2.598 & .036 \\
& Within Groups & 2375697.254 & 395 & 6014.423 & & \\
\hline \multirow{3}{*}{ Dynamic Capabilities } & Total & 2438193.750 & 399 & & & \\
\hline & Between Groups & 17208.917 & 4 & 4302.229 & 1.980 & .097 \\
& Within Groups & 858147.923 & 395 & 2172.526 & & \\
\hline & Total & 875356.840 & 399 & & & \\
\hline
\end{tabular}

As table 5 presented. It can be seen that the significance of educational level factor to dynamic capabilities and its dimensions. If obtained $F_{\text {value }}>F_{\text {table, then }} \mathrm{H}_{\mathrm{o}}$ is rejected, which means there are differences from a level of education factor (elementary school, junior high school, senior high school, Diploma III, and Diploma IV/Bachelor) to the dynamic capabilities along with its dimensions. The results obtained sensing capability value ( $F_{\text {value }}$ is 1.683 with $F_{\text {table }}$ of 2.395$)$, it shows that $F_{\text {value }}$ $<\mathrm{F}_{\text {table }}\left(\mathrm{H}_{\mathrm{o}}\right.$ is accepted). Which means that there is no difference in the level of education to the sensing capability of the traditional market traders in Bandung. The result of the value of absorptive capability $\left(F_{\text {value }}\right.$ is 0.623 with $F_{\text {table }}$ of 2,395$)$, it shows that $F_{\text {value }}<F_{\text {table }}\left(H_{\circ}\right.$ is accepted). Which means that there is no difference in the level of education to capability absorption of traditional market traders in Bandung.

The results obtained the value of integration capability $F_{\text {value }}$ is 1.013 with $F_{\text {table }}$ of 2.395 , it shows that $F_{\text {value }}<F_{\text {table }}\left(H_{\circ}\right.$ is accepted). Which means that there is no difference in the level of education to the integration capabilities of the traditional market traders in Bandung. The result of the value of innovation capability of $F_{\text {value }}$ is 2,598 with $F_{\text {table }}$ equal to 2,395 , that show that $F_{\text {value }}$ $>F_{\text {talbe }}\left(\mathrm{H}_{\mathrm{o}}\right.$ is rejected). So it can be concluded that there are differences in the level of education to the innovation capability of the traditional market traders in Bandung. The results obtained dynamic capabilities value $F_{\text {value }}$ is 1.980 with $F_{\text {table }}$ of 2.395 , it shows that $F_{\text {value }}<F_{\text {table }}\left(H_{\circ}\right.$ is accepted). Which means that there is no difference in the level of education against to the dynamic capabilities of the traditional market traders in Bandung. 


\subsubsection{Experience}

This result of the dynamic capabilities and its dimensions in terms of experience (over 15 years, 10 to 15 years, 5 to 10 years and less than 5 years) of respondents using One Way -ANOVA Test. The purpose of this test is to find out whether there are differences in dynamic capabilities along with the dimensions of the traditional market traders in Bandung who have experienced more than 15 years, 10 to 15 years, 5 to 10 years and less than 5 years. For more details can be folded in table 6.

Table 6: ANOVA-Experience

\begin{tabular}{|ll|c|c|c|c|c|}
\hline & & Sum of Squares & df & Mean Square & F & Sig. \\
\hline \multirow{3}{*}{ Sensing Capability } & Between Groups & 1812.017 & 3 & 604.006 & .237 & .871 \\
& Within Groups & 1010131.733 & 396 & 2550.838 & & \\
& Total & 1011943.750 & 399 & & & \\
\hline \multirow{3}{*}{ Absorptive Capability } & Between Groups & 1200.296 & 3 & 400.099 & .103 & .958 \\
& Within Groups & 1542774.704 & 396 & 3895.896 & & \\
& Total & 1543975.000 & 399 & & & \\
\hline \multirow{3}{*}{ Integration Capability } & Between Groups & 37399.814 & 3 & 12466.605 & 2.497 & .059 \\
& Within Groups & 1977200.186 & 396 & 4992.930 & & \\
\hline \multirow{2}{*}{ Innovation Capability } & Total & 2014600.000 & 399 & & & \\
& Between Groups & 27761.099 & 3 & 9253.700 & 1.520 & .209 \\
& Within Groups & 2410432.651 & 396 & 6086.951 & & \\
\hline \multirow{2}{*}{ Dynamic Capabilities } & Total & 2438193.750 & 399 & & & \\
& Between Groups & 8189.983 & 3 & 2729.994 & 1.247 & .292 \\
& Within Groups & 867166.857 & 396 & 2189.815 & & \\
\hline & Total & 875356.840 & 399 & & & \\
\hline
\end{tabular}

The impact of the experience of the traditional market (more than 15 years, between 10 to 15 years, between 5 to 10 years, and less of 5 years) to the dynamic capabilities and its dimensions, when $F_{\text {value }}>F_{\text {table, }}$ it show that $H_{0}$ is rejected. Which means there is a difference between the experience of the dynamic capabilities and its dimensions. The results obtained sensing capability value $\left(F_{\text {value }}\right.$ is 0.237 with $F_{\text {table }}$ of 2.627 ), it shows that $F_{\text {value }}<F_{\text {table }}$ (Ho is accepted). So it can be concluded that there is no difference in the experience of the sensing capability of the traditional market traders in Bandung. The result of the value of absorptive capability is $F_{\text {value }}$ is 0,103 with $F_{\text {table }}$ equal to 2,627 , it shows that $F_{\text {value }}<\mathrm{F}_{\text {table }}$ (Ho is accepted). Which means that there is no difference in the experience to the absorptive capability of the traditional market traders in Bandung.

The result of the integration capability value ( $F_{\text {value }}$ is 2,497 with $F_{\text {table }}$ of 2,627$)$, it shows that $F_{\text {value }}<F_{\text {table }}\left(H_{\circ}\right.$ is accepted). Which means that there is no difference in experience (more than 15 years, between 10 to 15 years, between 5 to 10 years, and less than 5 years) to the integration capability of traditional market traders in Bandung. The results value of innovation capability $\left(F_{\text {value }}\right.$ 1.520 with $F_{\text {table }}$ of 2.627), it shows that $F_{\text {value }}<F_{\text {table }}\left(H_{o}\right.$ is accepted). Which means that there is no difference in the experience (more than 15 years, between 10 to 15 years, between 5 to 10 years, and less than 5 years) to the innovation capability of traditional market traders in Bandung. The results obtained dynamic capabilities value $\left(F_{\text {value }}\right.$ is 1.247 with $F_{\text {table }}$ of 2.627$)$, it shows that $F_{\text {value }}$ $<\mathrm{F}_{\text {table }}\left(\mathrm{H}_{\mathrm{o}}\right.$ is accepted). Which means that there is no difference in the experience (more than 15 years, between 10 to 15 years, between 5 to 10 years, and less than 5 years) to the dynamic capabilities of traditional market traders in Bandung.

\subsection{Discussion}

From the research results, it can be seen that demographic factors (gender, level of education, and experience) and its effect on dynamic capabilities and its sub-dimensions (sensitivity capability, 
absorptive capability, integration capability and innovation capability). The formulated hypothesis can be known as Table 7.

The results of hypothesis testing are known, that the first hypothesis $\left(\mathrm{H}_{1}\right)$ shows that reject $\mathrm{H}_{\mathrm{a}}$, so it can be concluded that there is a difference in dynamic capabilities of traditional market traders in Bandung between male and female. Male has better capability than women, this condition occurs because male respondent is bigger than female, and a general trend in the traditional market, husband and wife couple become traders in the same place. This condition is not in line with Hambrick and Mason (1984) states that the characteristics of managers (eg, demographic characteristics) influence the decisions they make and therefore the actions adopted by the organizations they manage. However, it differs from the sub-hypothesis. Where the sensing capability $\left(\mathrm{H}_{1.1}\right)$, integration capability $\left(\mathrm{H}_{1.3}\right)$, and innovation capability $\left(\mathrm{H}_{1.4}\right)$, it shows that $\mathrm{H}_{a}$ is accepted. So it can be concluded that there is no difference of male and female in the sensing capability, integration capability, and innovation capability. While for absorption capability $\left(\mathrm{H}_{1.2}\right)$, it shows that $\mathrm{H}_{\mathrm{a}}$ is rejected. So it can be concluded that there is a difference absorption capability between male and female from the traditional market traders in Bandung

Table 7: Hypothesis Test

\begin{tabular}{|c|c|c|c|c|c|}
\hline \multicolumn{2}{|c|}{ Hypothesis and Sub-Hypothesis } & \multirow{2}{*}{$\mathbf{F}$} & \multirow{2}{*}{ Sig. } & \multicolumn{2}{|c|}{ Result } \\
\cline { 5 - 6 } & & & $\mathbf{H}_{\mathbf{a}}$ & $\mathbf{H}_{\mathbf{o}}$ \\
\hline $\mathrm{H}_{1}$ & & 6,1900 &, 013 & rejected & accepted \\
\hline & $\mathrm{H}_{1.1}$ & 2,2380 &, 135 & accepted & rejected \\
\hline & $\mathrm{H}_{1.2}$ & 4,2330 &, 040 & rejected & diterima \\
\hline & $\mathrm{H}_{1.3}$ & 3,1720 &, 076 & accepted & rejected \\
\hline & $\mathrm{H}_{1.4}$ & 2,9070 &, 089 & accepted & rejected \\
\hline $\mathrm{H}_{2}$ & & 1,9803 &, 097 & accepted & rejected \\
\hline & $\mathrm{H}_{2.1}$ & 1,6834 &, 153 & accepted & rejected \\
\hline & $\mathrm{H}_{2.2}$ & 0,6229 &, 646 & accepted & rejected \\
\hline & $\mathrm{H}_{2.3}$ & 1,0129 &, 400 & accepted & rejected \\
\hline & $\mathrm{H}_{2.4}$ & 2,5978 &, 036 & rejected & accepted \\
\hline $\mathrm{H}_{3}$ & & 1,0600 &, 304 & accepted & rejected \\
\hline & $\mathrm{H}_{3.1}$ & 0,6340 &, 426 & accepted & rejected \\
\hline & $\mathrm{H}_{3.2}$ & 1,5080 &, 220 & accepted & rejected \\
\hline & $\mathrm{H}_{3.3}$ & 0,8090 &, 369 & accepted & rejected \\
\hline & $\mathrm{H}_{3.4}$ & 3,2390 &, 730 & accepted & rejected \\
\hline & & 3,6610 &, 560 & accepted & rejected \\
\hline $\mathrm{H}_{4}$ & $\mathrm{H}_{4.1}$ & 7,1620 &, 008 & rejected & accepted \\
\hline & $\mathrm{H}_{4.2}$ & 0,1690 &, 681 & accepted & rejected \\
\hline & $\mathrm{H}_{4.3}$ & 3,9810 &, 047 & rejected & accepted \\
\hline & $\mathrm{H}_{4.4}$ & 0,5060 &, 477 & accepted & rejected \\
\hline & & 1,2470 &, 292 & accepted & rejected \\
\hline & $\mathrm{H}_{5.1}$ & 0,2370 &, 871 & accepted & rejected \\
\hline $\mathrm{H}_{5}$ & $\mathrm{H}_{5.2}$ & 0,1030 &, 958 & accepted & rejected \\
\hline & $\mathrm{H}_{5.3}$ & 2,4970 &, 059 & accepted & rejected \\
\hline & $\mathrm{H}_{5.4}$ & 1,5200 &, 209 & accepted & rejected \\
\hline & & & & \\
\hline & & & & & \\
\hline & & & & &
\end{tabular}

The result of the second hypothesis $\left(\mathrm{H}_{2}\right)$ shows that $\mathrm{H}_{\mathrm{a}}$ is accepted. So it can be concluded that there is no difference of dynamic capabilities to the level of education of the traditional market traders in Bandung. This condition occurs because the level of education of respondents is a mostly high school $(56 \%)$, then junior high $(28 \%)$, those who are educated diploma or bachelor with a very small $(5 \%)$. The facts show that people who have higher education tend to choose the profession, not as a trader. This research finding is different from Box, White, and Barr, (1993) which states the level of education influences the achievement of results. The same thing was also expressed by Daneels (2008) and Birley and Norburn (1987). Other findings show that most of the subhypotheses, namely; sensing capability $\left(\mathrm{H}_{2.1}\right)$, absorptive capability $\left(\mathrm{H}_{2.2}\right)$, and integration capability 
$\left(\mathrm{H}_{2.3}\right)$, it show that $\mathrm{H}_{\mathrm{a}}$ is accepted. so it can be concluded that there is no difference in the level of education of traditional market traders in Bandung in the sensing capability, integration capability and the innovation capability. While for the absorption capability $\left(\mathrm{H}_{1.2}\right)$, it shows that $\mathrm{H}_{\mathrm{a}}$ is rejected. So it can be concluded that there is a difference between innovation capability of the level of education from the traditional market traders in Bandung.

The last hypothesis $\left(\mathrm{H}_{3}\right)$ showed that $\mathrm{H}_{\mathrm{a}}$ is accepted. So it can be concluded that there is no difference in dynamic capabilities to the experience of the traditional market traders in Bandung. This condition occurs because the average trader has traded in the traditional market for 10 to 15 years and they have been walked down the huddle of parents. The facts show that the experience carried out is not an absolute requirement of the merchants to be able to increase their capability in obtaining, producing and combining knowledge resources aimed at the feeling, exploring and environmental dynamics. in traditional markets (Zheng, et al; 2011). This finding is different from Box et al (1993) which suggests that an entrepreneur's experience is positively correlated with performance, this opinion is also supported by subsequent research such as Box, Watts, and Hisrich (1994); Yusuf (1995). In addition, Boohene (2009) found that lack of education and work experience contribute to the inability of female owners to effectively manage a business. While many studies have looked at the direct effect of demographic characteristics on performance, we estimate that the owner's age, educational level, and prior experience affect the strategic capabilities of each company and in turn the overall performance of the company. It's also for subhypothesis, that is; sensing capability $\left(\mathrm{H}_{3.1}\right)$, absorptive capability $\left(\mathrm{H}_{3.2}\right)$, integration capability $\left(\mathrm{H}_{3.3}\right)$ and innovation capabilities $\left(\mathrm{H}_{3.4}\right)$, all accept $\mathrm{H}_{\mathrm{a}}$. So it can be concluded that there is no difference in experience in sensing capability, absorptive capability, integration capability and innovation capability.

\section{Conclusion}

Based on the results the demographic perspective on the dynamic capabilities of the traditional market traders in Bandung, it can be concluded that the dynamic capabilities of traditional market traders in Bandung, descriptively seen from the perspective of demography shows. Viewed from the level of education, indicates that the level of dynamic capabilities in the category is good enough, for the overall dynamic capabilities as well as each dimension, both sensing capability, absorptive capability, integration capability and innovation capability. Just as at the level of educational, it shows that there is no difference in dynamic capabilities at a sufficiently good level. Similarly, for the sensing capability, absorption capability, integration capabilities and innovation capabilities.

The demographic difference to the dynamic capabilities of the traditional market traders in Bandung shown, that the gender does not differ in dynamic capabilities, as well as for each dimension; sensing capabilities, integration capabilities and innovation capabilities, only the absorptive capability there are differences between male and female. The level of education as a whole does not show the different levels of dynamic capabilities of the traditional market traders in Bandung, along with their dimensions, namely; sensing capability, absorption capability, and integration capability. While the innovation capability shows the different levels of education.

\section{References}

Box, T.M., Watts, L.R., and Hisrich, R.D. (1994). Manufacturing entrepreneurs: An empirical study of the correlates of employment growth in the Tulsa MSA and rural East Texas. Journal of Business Venturing, 9(3), 261-270.

Box, T.M., White, M.A., and Barr, S.H. (1993). A Contingency Model of New Manufacturing Firm Performance, Entrepreneurship: Theory and Practice, 18(2), 31-46.

Boohene, R. (2009). The relationships among Gender, Strategic Capabilities, and Performance of Small Retail Firms in Ghana. Journal of African Business, 10,121-138.

Brush, C. (1992).Research on women business owners: Past trends a new perspective and future directions. Entrepreneurship: Theory and Practice, 16(4), 393-407. 
Cooper, A.C. (1981). Strategic management: new ventures and business performance. Long Range Planning, 14(5), 39-45

Cooper, D.R, and Schindler, P.S. (2010). Business Research Methods, (12 ${ }^{\text {th }}$ Edition), McGraw-Hill/lrwin, New York

Dadashinasab, M, and Sofian, S. (2014). The Impact of Intellectual Capital on Firm Financial Performance by Moderating of Dynamic capabilities, Asian Social Science; 10(17), 93-100.

Daneels, E. (2008). Organizational antecedets of second-order competences. Strategic Management Journal, 29(5), 519-543.

Gathungu, J.M. and Mwangi, J.K. (2012). Dynamic Capabilities, Talent Development and Firm Performance, DBA Africa Management Review, 2 (3), 83-100.

Hambrick, D.C. and Mason, P.A. (1984). Upper echelons: The organization as a reflection of its top managers. Academy of Management Review, 9(2) 193-206

Hou, J.J. (2008). toward a Research Model of Market Orientation and Dynamic Capabilities. Social Behavior and Personality, 36(9) pp 1251-1268

Indonesia Retail Report (2013) Including 5-year Industry Forecasts by BMI, Business Monitor International, London, UK

Lin, K.W and Huang, K.P. (2012). Dynamic capabilities and Its Effect on Firm Performance. American Journal of Applied Sciences, 9(1), 107-110

Malhotra, N.K., Baalbaki, I.B. and Bechwati, N.N. (2003) Marketing Research, Pearson-Education Limited, UK

Najib, M.F., Kartini, D., Suryana, Y. and Sari, D. (2017) 'Market orientation, buyer-supplier relationship and firm performance with dynamic capabilities as an intervening variable: a research model', Int. J. Business and Globalisation, 19(4), 567-582.

Nedzinskas, S., Pundziene, A., Rafanaviciene, S.B and Pilkiene, M (2013). The impact of dynamic capabilities on SME performance in a volatile environment as moderated by organizational inertia, Baltic Journal of Management, 8(4), 376-396

Nunally, J.C., and Bernstein, I.H. (1994). Psychometric theory (3rd). McGraw Hill, New York

Pavlou, P.A., and El-Sawy, O.A. (2011). Understanding the Elusive Black Box of Dynamic Capabilities, Journal of Decision Sciences, 42(1), 239-273

Sekaran, U, and Bougie, R. (2009). Research Methods for Business- A Skill Building Approach. (5 ed.). John Wiley and Son Ltd, United Kingdom

Suryadarma, D., Poesoro, A., Budiyati, S., Akhmadi. and Rosfadhila, M. (2007). Dampak Supermarket terhadap Pasar dan Pedagang Ritel Tradisional di Daerah Perkotaan di Indonesia.(Impact of Supermarkets on Traditional Retail Market and Traders in Urban Areas in Indonesia). SMERU

Teece, D.J. (2007). Explicating Dynamic Capabilities: The Nature and Micro foundation of (Sustainable) Enterprise Performance. Strategic Management Journal, 28, 1319-1350

Tiantian, G., Yezhuang, T and Qianqian, Y. (2014). Impact of Manufacturing Dynamic Capabilities on Enterprise Performance- The Nonlinear Moderating Effect of Environmental Dynamism., Journal of Applied Sciences, 14(18), 2067-2072.

Tsai, P.C.F., and Shih, C.T. (2013). Responsible downsizing strategy as a panacea to firm performance: the role of dynamic capabilities. International Journal of Manpower, 34(8), 1015-1028

Wang, Y., and Shi, X. (2011). Thrive, not just survive enhance dynamic capabilities of SMEs through IS competence, Journal of Systems and Information Technology, 13(2), 200-222

Yusuf, A. (1995). Critical success factors for small business: Perceptions if South Pacific entrepreneurs. Journal of Small Business Management, 33(2), 68 - 76

Zheng, S., Zhang, W., Wu, X. and Du, J. (2011). Knowledge-based dynamic capabilities and innovation in networked environments, Journal of Knowledge Management, 15(6), 1035-1051 